\title{
Çocuklarda Obezitenin Önlenmesi ve Yönetiminde Hemşirenin Rolü
}

\author{
The Role of Nurses in the Prevention and Management of \\ Obesity in Children
}

\section{Leyla ERDIM ${ }^{1}$}

Ayşe ERGUN ${ }^{2}$

Sema KU $\breve{G} U O \breve{G} L U^{3}$

${ }^{1} \dot{I}$ stanbul Üniversitesi, Sağllk Bilimleri Fakültesi, Ebelik Bölümü

${ }^{2}$ Marmara Üniversitesi, Sağllk Bilimleri Fakültesi, Hemşirelik Bölümü, Halk Să̆lı̆̆ Hemşireliği Anabilim Dalı

${ }^{3}$ Marmara Üniversitesi, Sağllk Bilimleri Fakültesi, Hemşirelik Bölümü, Çocuk Să̆llğ ve Hastalıkları Hemşireliği Anabilim Dalı Emekli Ögretim Üyesi

Yazışma Adresi Correspondence Dr. Leyla Erdim Istanbul Üniversitesi, Sağlık Bilimleri Fakültesi, Ebelik Bölümü Demirkapı Cad. Karabal Sok. Bakırköy Ruh ve Sinir Hastalıkları Hastanesi Bahçesi içi 34740 Bakırköy/Istanbul Tel: 9002124141500 leylaerdim@gmail.com

Geliş Tarihi/Recevied 24/08/2014

Kabul Tarihi/Accepted 22/09/2014

HSP 2014;1(2):115-126

\section{Özet}

Obezite birçok sağlık sorununu beraberinde getirebileceği için tedavisinden çok gelişiminin önlenmesi önemlidir. Çocuk ya da adolesan obezitesini önleme girişimleri, tedavi edilmesine kıyasla daha etkili ve daha az maliyetlidir. Bunun için önleme çalışmalarına çocukluk çağında başlanması önemlidir. Hemşireler sağllk eğitimi yoluyla ilgilendikleri grupların sağlıklarının korunmasında ve geliştirilmesinde önemli etkiye sahiptirler. Hemşirelerin yenidoğan döneminden başlayarak adolesan dönemini de kapsayacak şekilde çocukların fazla tartılılığına neden olan değiştirilebilir sağlık davranışları (çocuğun beslenme ve aktivite alışkanlığ ile sedanter davranışı) ve onların tartı durumlarına etki eden aile çevresinin sağlık davranışları (beslenme ve aktivite alışkanlıkları) konusunda çocuk ve aileye yapacakları beslenme ve sağlık eğitimi obezite ile mücadelede son derece önemlidir.

Anahtar Kelimeler: Çocuk, hemşirelik, obezite.

\section{Abstract}

Since obesity is the source of many comorbidities, the main point of focus should be the prevention of its development, and not its consequent treatment. Interventions aimed at preventing childhood or adolescent obesity are more efficient and costeffective than its treatment. In this regard, it is important to initiate prevention programs during childhood. Nurses play a crucial role in protecting and promoting health in various groups via health education. Nutrition and health education, which include information on modifiable health behaviors that cause overweight in children (nutritional and exercise habits and sedentary behavior in children) and on familial health behaviors that affect children's weight (nutritional and exercise habits), should be provided for children and families by nurses starting from the neonatal period and extending to adolescence in order to fight obesity.

Key Words: Child, nursing, obesity. 


\section{HEMŞIRELIK}

\section{Giriş}

Dünya Sağlık Örgütü (DSÖ)'nün sağlığı bozacak ölçüde vücutta anormal veya aşırı yağ birikmesi şeklinde tanımladığı obezite tüm dünyada hızlı bir şekilde artarak yüzyılın en önemli halk sağlığı sorunlarından biri durumuna gelmiştir. ${ }^{36-37}$

Tüm dünyada obezitenin oranı son 30 yılda iki kattan daha fazla artmıştır. ${ }^{37}$ Obezite erişkin yaş gruplarını etkilediği gibi çocuk ve adolesanları da etkileyerek yaygınlığı endişe verici boyutlara ulaşmıştır. Amerika Birleşik Devletlerinde Ulusal Beslenme ve Sağlık Araştırması (NHANES 2011-2012) sonuçlarına göre 2-19 yaş arasındaki çocuk ve adolesanlardaki obezite oranı \% 16.9 (12.5 milyon), yenidoğan ve okul öncesi çocuklarda \% 8.1 olarak belirlenmiştir. ${ }^{24}$ Dünya Sağlık Örgütü (DSÖ) Avrupa Bölgesi Çocukluk Çağ1 Şişmanlığın İzlenmesi araştırmasına (COSI-2009-2010) göre 6-9 yaş aralığındaki erkek çocuklardaki fazla tartılılık prevalansı \% 57 ile \% 18, kız çocuklarında \% 50 ile \% 18, obezite prevalansı ise erkeklerde $\% 31$ ile $\% 6$, kızlarda ise $\% 21$ ile $\% 5$ arasında bulunmuştur. ${ }^{40}$

Ülkemiz içinde çocukluk çağı obezitesi önemli bir sağlık sorunudur. ${ }^{33}$ Sağlık Bakanlığının 2010 yılında yaptığı Türkiye Beslenme ve Sağlık Araştırması (TBSA) sonuçlarına göre 0-5 yaş grubu çocuklarda fazla tartılık oranı $\% 17.9$, obezite oranı $\% 8.5,6$ 18 yaş grubu çocuklarda ise fazla tartılık oranı \% 14.3, obezite oranını \% 8.2 olarak belirlenmiştir. $^{32}$

Global olarak çocukluk obezitesindeki bu hızlı artış birçok fizyolojik ve psikolojik probleme yol açarak, ülke ekonomilerini de olumsuz yönde etkilemektedir. Obezite ile diyabet, hipertansiyon, kas ve iskelet sistemi sorunları, hiperlipidemi, solunum sistemi hastalıkları, serebrovasküler hastalıklar arasında sıkı bir ilişki vardır. Obezite, çocuk ve adolesanları bu tür hastalıklara yatkın hale getirmekte veya daha erken yaşlarda ortaya çıkmasına sebep olarak yaşam kalitesini düşürmektedir. ${ }^{\text {7,23, 33, 37, } 39}$ Ayrıca benlik saygısında düşme, depresyon ve sosyal ilişkilerden uzaklaşma şeklinde psiko-sosyal sorunlara da neden olabilmektedir. ${ }^{16,20}$ Obez çocuk ve adolesanların yetişkinlikte de obez kalma olasılıkları daha yüksektir. Obez çocukların 1/3'ü, obez adolesanların ise \% 80'i erişkin yaşa ulaştıklarında obez kalmaktadırlar. ${ }^{9}$ Bu olumsuz nedenlerden dolayı çocukluk çağı obezitenin önlenmesi, erken dönemde tanılanması ve tedavisi çocukluk ve erişkin dönemde obeziteye bağlı ortaya çıkabilecek komplikasyonların önlenmesi açısından önemlidir. ${ }^{19}$

$\mathrm{Bu}$ makalenin amacı, çocuklarda obezitenin önlenmesi ve yönetiminde hemşirenin rolünü incelemektir. 


\section{Obezite Yönetiminde Hemşirenin Rolü}

Hemşirelerin obezite ile mücadelede, sağlık bakım hizmetlerinin tüm aşamalarında (koruyucu, tedavi edici, rehabilite edici) hastalığın önlenmesi, tedavisi ve bakımında önemli sorumlulukları bulunmaktadır. Bütün basamaklarda amaç, vücut ağırlığını normal sınırlarda tutmak veya normal sınırlara indirmektir. ${ }^{22,28}$ Obeziteye neden olduğu bilinen çok sayıda faktör içinde, aşırı ve yanlış beslenme ve fiziksel aktivite yetersizliği en önemli nedenler olarak kabul edilmektedir. ${ }^{33}$ Hemşireler obezite veya fazla tartılı olma riskini azaltacak sağlıklı beslenme ve fiziksel aktiviteyi geliştirmede çocuk, aile ve toplum için eğitici ve rol model olarak ideal pozisyondadırlar. Obeziteyi önlemeye yönelik araştırma kanıtlarına dayalı sağlıklı yaşam programları oluşturabilirler. Obezite yönetiminde; eğitim, bakım yönetimi ve destek sağlama gibi hemşirelik girişimleri, çocuklar ve ergenlerdeki obezite probleminin çözümünde gerekli stratejilerinin oluşturulmasında, uygulanmasında ve değerlendirilmesinde önemlidir. $^{28}$

Çalışmalarda çocukluk obezitesini önleme ve tedavi programlarında ailelerin de yer almasının programın başarısını arttırdığı belirtilmektedir. ${ }^{8,13-14} \mathrm{Bu}$ nedenle hemşirelerin obezitenin önlenmesi ve yönetiminde aileler ile birlikte çalışmaları ve çocukları için olumlu model oluşturmaları açısından aileyi bilinçlendirilmeleri gereklidir. Hemşireler bu uygulamalarını okullarda, toplum sağ lı̆̆ merkezlerinde ve birinci basamak sağl1k kurumları ya da evde sağlam çocuk muayeneleri sırasında yapabilirler. ${ }^{28}$

Obezite yönetimi; obezitenin önlenmesi, erken tanı ve tedavisi ile birlikte obezitenin yaratacağı veya artışına neden olacağı sağlık sorunlarının giderilmesini içeren birincil, ikincil ve üçüncül koruma düzeylerine yönelik girişimleri kapsar. Her aşamada yapılacak önerilerin birbirinden net sınırlarla ayrılması güçtür. Çünkü obezite gelişmeden önce alınacak önlemler ve obezite tanısı sonrası yaklaşım tarzları birbirlerine benzemektedir. ${ }^{26,28}$

\section{Birincil koruma}

Obez olmayan bireylerde obezite ile ilgili patolojik değişimlerin gelişmesini önlemek amacıyla yapılan sağlıklı yaşam biçiminin geliştirilmesi girişimleridir. Hemşireler obeziteyi önlemede obezitenin en sık görüldüğü yaş dönemlerine göre çocuk ve aileyi kapsayan eğitimlerinde sağlıklı beslenme ve fiziksel aktivitenin önemi üzerinde durmalıdır. ${ }^{28}$

Yenidoğan ve bebeklik döneminde obezitenin önlenmesi için en uygun girişim hemşirelerin annelere yapacakları anne sütü beslenme danışmanlığıdır. Bu dönemde bebek için, yaşına uygun alınması gereken enerji ve besin öğelerini sağlayacak en ideal besin anne sütüdür. Anne sütü ile beslenme obeziteyi engellemektedir. ${ }^{17,31}$ 


\section{HEMŞIRELIK}

Çocuk ve adolesan gruplarında ise hemşireler obeziteyi önlemeye yönelik aileyi de içine alan sağlık eğitimi programları yapabilirler. Hemşire günde en az beş porsiyon meyve ve sebze tüketilmesi, karbonatlı ve kolalı içeceklerin tüketilmemesi ya da en aza indirilmesi, fastfood tüketiminin sınırlandırılması konularında çocuk ve aileyi bilgilendirmelidir. Ebeveynler çocuklarının beslenme ve aktivite davranışına yönelik kurallar geliştirme ve uygulama yönünde cesaretlendirilmelidir. Aile olarak her gün kahvaltı yapılmalı, dışarıda mümkün olduğunca az yemek yenmelidir. Tüm aile üyeleri haftada en az beş-altı kez hep birlikte yemek yemelidir. Yemekler televizyon karşısında yenmemeli, ebeveynler çocuklarına yiyeceği hiçbir zaman ödül olarak kullanmamalıdır. Çocuklarına ögünlerini her gün düzenli tüketme alışkanlığı kazandırarak ve sağlıklı besinler yiyerek örnek olmalıdırlar. ${ }^{11,30}$

Sağlıklı beslenmenin yanı sıra çocuğun fazla televizyon izleme ve bilgisayar kullanma gibi hareketsiz davranışları sınırlandırılmalı, fiziksel aktivite için cesaretlendirilmelidir. Ebeveynler aktif yaşam tarzını benimseyerek düzenli fiziksel egzersiz yaparak çocuklarına örnek olmalıdır. Ebeveyn ve çocuğun birlikte yapabileceği yürüyüş, dans, top oynama gibi eğlenceli fiziksel aktiviteler önerilebilir. Hemşire çocuğun televizyon izleme ve bilgisayar başında geçirdiği zamanı günde iki saat ile sınırlandırılması, yattığı odada televizyon bulundurulmaması ve günde en az bir saat fiziksel aktivite yapmasının önemi konusunda ebeveynleri bilgilendirmelidir. ${ }^{11,30}$

\section{Ikincil koruma}

Erken teşhis ve birey için gerekli uygulamalardan oluşmaktadır. Obezitenin erken dönemde belirlenmesi ve uygun şekilde tedavisi ile birey sağlı̆̆ını yeniden kazanabilir. İkincil korumanın içeriğinde sağlık taramaları ve periyodik muayeneler yer alır. ${ }^{28}$

Hemşire çocuğun fazla tartılı veya obez olduğunu belirlediğinde girişim planlamadan önce tam bir değerlendirme yapmalıdır. Ayrıntılı değerlendirmede hemşire; çocuğun aile öyküsünü (kalp hastalıkları, diyabet, obezite, yüksek tansiyon, hiperlipidemi, pankreatik hastalıklar ve iskelet hastalıkları), günlük besin alımını, aktivitesini ve tartı kontrolü için yapılan önceki girişimleri sorgulamalı, boy ve tartısını ölçerek, vücut sistemlerini incelemelidir. Veriler değerlendirildikten sonra çocuğun "Vücut Kitle İndeksi" (VKİ) hesaplanmalıdır. ${ }^{28}$ VKİ [vücut tartısı(kg)/boy( $\left.\mathbf{m}^{2}\right)$ ] formülüne göre hesaplanır. Çocuklarda VKİ yaş ve cinsiyete göre farklılık gösterir. ${ }^{15}$ Eğer çocuğun VKI'si yaş ve cinse göre belirlenmiş çizelgelerde 95. persentilin üzerindeyse obez, 85-95 persentil arasında ise fazla tartılı olarak tanımlanır. ${ }^{10,25,34}$

Hemşire çocuğun obez ya da fazla tartılı olduğunu belirledikten sonra ebeveynlerin 
çocuklarının tartısı konusundaki algılarını değerlendirmelidir. Çünkü ebeveynlerin çocuklarının tartılarını doğru biçimde algılamaları yani fazla tartılı ya da obez olduğunun farkında olmaları yaşam biçimini değiştirmeye istekli olmalarını ve girişimlerin başarısını etkileyecektir. $^{29}$

Hemşire daha sonra çocuğun yaşına uygun sağlıklı beslenmeyi ve fiziksel aktiviteyi geliştirecek aile eğitimine başlamalı ve gerekli durumlarda diyetisyen ile işbirliğ yapmalıdır. ${ }^{6,29}$ Eğitimde; öncelikle diyabet, kardiyovasküler hastalıklar ve hipertansiyon gibi obezite ile ilişkili sağlık sorunları hakkında kapsamlı bilgi vermeli, sağlıklı beslenme ve fiziksel aktivitenin önemini vurgulamalıdır.

Hemşire bebeklik döneminde anneye yapacağı eğitimde özellikle çocuğun büyümesinin izlenmesi (büyüme eğrileri konusunda bilgi verilmeli), ayına uygun beslenmesi ve yanlış bebek besleme davranışlarının düzeltilmesi üzerinde durmalıdır. Bunun için bebeğini ilk 6 ay sadece anne sütü ile beslemesi, bebeğin her ağlamasını açlık işareti olarak algılamaması ve bebeği beslemek yerine susturmak için başka yöntemler bulması, ek besinlere zamanında başlaması (6. ay), ek besinlerin uygun kalite ve miktarda olmasına dikkat etmesi, besinlere tuz ve şeker eklememesi, ek besinleri verirken kaşık kullanması, bebeği hazır bebek mamaları (formül süt) ile besliyorsa mamayı tarife göre hazırlaması ve biberondaki mamanın miktarının bebeğin ayına uygun olması, mamayı hazırlarken su yerine süt kullanmaması, ek besin olarak unlu-şekerli (muhallebi) tercih etmemesi, hazır bebek mamalarına bisküvi, ekmek, un, şeker, yağ eklememesi gerektiği üzerinde durmalıdır. ${ }^{2,27,38}$

Çocukluk ve adolesan döneminde ise hemşire beslenme eğitimini yapmadan önce ebeveynlerin çocuk besleme tutum ve davranışlarını, evde sağlıklı ve sağlıksız bulunan besinleri ve çocukların bunlara ulaş1labilirliğini ve ebeveynlerin sergiledikleri beslenme davranışlarını bilmelidir. ${ }^{5-6,29}$ Öncelikle obezite gelişiminde rol oynayan hatalı beslenme davranışının düzeltilmesi gereklidir. Hatalı beslenmenin düzeltilmesi için yemek içeriğinin ve yemek yeme biçiminin düzenlenmesi gerekir. Yemek içeriğinin düzenlenmesinde; kolalı ve gazlı içecekler, hazır meyve suları, çikolata, gofret, dondurma, şeker, pasta, kek gibi şişmanlatıcı gıdaların kısıtlanması, makarna, pilav, börek, mantı, hamurlu ve sütlü tatlılar, yăg ve yağda kızarmış yiyecekler gibi karbonhidratlı ve yağdan zengin gıdaların kısıtlanması, kalori bakımından zengin abur-cubur diye adlandırılan yiyeceklerin atıştırılmasının önlenmesi, hamburger, pizza, tost, döner ekmek gibi hazır yemeklerin yenmemesinin gerekliliği vurgulanmalıdır. Sınırlı tüketimi önerilen tüm atıştırmalık ve hazır yiyeceklerin evde bulundurulmaması özellikle belirtilmelidir. Yemek yeme biçiminin düzenlenmesinde 


\section{HEMŞIRELIK}

ise; hızlı yemenin, s1k ve seyrek yemenin terk edilmesi, gece yatmadan önce kalori bakımından zengin yiyeceklerin alınmaması gereklidir. ${ }^{29,41}$

Hemşire yaş ve cinse göre gerekli miktarda besin alımını içeren yeni bir yaşam stili kurulmasına destek olmalıdır. ${ }^{6}$ Beslenme eğitiminde özellikle çocuk için gerekli olan besinler üzerine odaklanılmalıdır. Çocuklara verilecek besinler normal büyüme ve gelişmeyi sağlayacak yeterli kalori ve esansiyel besinleri içeren, protein, karbonhidrat ve yağ içeriği bakımından dengeli olmalıdır. Her besin grubu için uygun porsiyonlarda ve geniş çeşitlilikte bir yiyecek listesi hazırlanmalıdır. Hemşire ayrıca aileye her bir besin grubunu ve bu besin grubundaki yiyeceklerin porsiyon büyüklügüünü gösteren beslenme piramidinin bir kopyasını sağlamalıdır. ${ }^{5,18,29}$ Özellikle sebze, meyve, düşük yağlı süt ürünleri ve kepekli tahıllar önerilebilir. Gerekli olandan daha az besin alımı boy uzamasının durmasına neden olacağı için önerilmez. Yiyeceklerini seçmede çocuğa özgürlük tanınmalı, kısıtlamalar aşırı olmamalidir. ${ }^{25,41}$

Hemşireler, ebeveynleri çocuklarını evlerinde menü planlama ve yemek hazırlama gibi uğraşlara katmaları için teşvik edebilirler. Ebeveynlerin çocukları ile yemeği birlikte hazırlaması, yemek hazırlamak için bir model oluşturur. Ayrıca çocuklar hazırlanmasına yardım ettikleri yemekleri yeme eğilimi gösterirler. Çocuklar bu şekilde sağlıklı yemek ve sağlıklı atıştırmanın nelerden oluştuğunu anlayabilirler. ${ }^{12,29}$ Hemşirelerin sağlıklı vücut tartısı hakkında aileyi bilgilendirmeleri de eğitimin önemli bir parçasıdır. Çünkü birçok ebeveyn fazla tartılı çocuk ve adolesan görmeye alışık oldukları için kendi çocuklarını fazla tartılı olarak görmeyebilmektedirler. $^{29}$

Çocuğun sağlıklı beslenmesi yanında aktif bir yaşam biçiminin geliştirilmesi de kilo kontrolünün önemli bir parçasıdır. Fiziksel aktivite sağlıklı bir beden için gerekli kas ve kemik gelişimini sağlarken aynı zamanda obeziteyi önlemede önemli bir adımdır. Hemşireler ebeveynlere fiziksel aktivitenin sağlık üzerindeki yararlarını anlatmalı, düzenli egzersizi bir aile aktivitesi haline getirip egzersiz yaparak çocuğa iyi bir model oluşturmaları için teşvik etmelidir. $^{6,11,22}$ Harcanan kalorinin artırılması için öncelikle günlük yürüyüş miktarının artırılması, merdiven kullanılması, kısa mesafelerde araba yerine yürümenin teşvik edilmesi, giyinmek, çanta hazırlamak, odanın düzenlenmesi gibi bireysel işlerin çocuk tarafından yapılmasının sağlanması gibi günlük aktivite içerisinde düzenlemelere gidildikten sonra düzenli egzersiz yapılması önerilir. ${ }^{4}$ Başlangıçta 15-20 dakika süreli haftanın üç-dört günü yapılan hafif tempoda yürüyüş, aerobik egzersizi gibi egzersizlerle başlanırken giderek egzersizin temposu, süresi, sayısı ve içeriği artırılmalıdır. ${ }^{3,11}$ Fiziksel aktivitenin şekli ve 
miktarından daha önemli olan süreklilik kazanmasıdır. $\mathrm{Bu}$ nedenle çocukların hareket etmekten hoşlanmaları ve bu davranışı yaşam boyu sürecek bir alışkanlığa dönüştürmeleri desteklenmelidir. Her çocuğun hoşlanacağı bir fiziksel aktivite bulunabilir. Aile ile birlikte günlük yürüyüşler, okul ya da diğer kurumların organize spor etkinliklerine katılma, dans etme, koşu, tırmanma, basketbol, futbol, bisiklete binme gibi aktiviteler önerilir. ${ }^{4-5-6,41}$

\begin{tabular}{|c|c|}
\hline & Çocukluk Obezitesinin Önlenmesine Yönelik Öneriler ${ }^{4,11,18,21,27,29,38}$ \\
\hline $\begin{array}{l}\text { Beslenme } \\
\text { Önerileri }\end{array}$ & 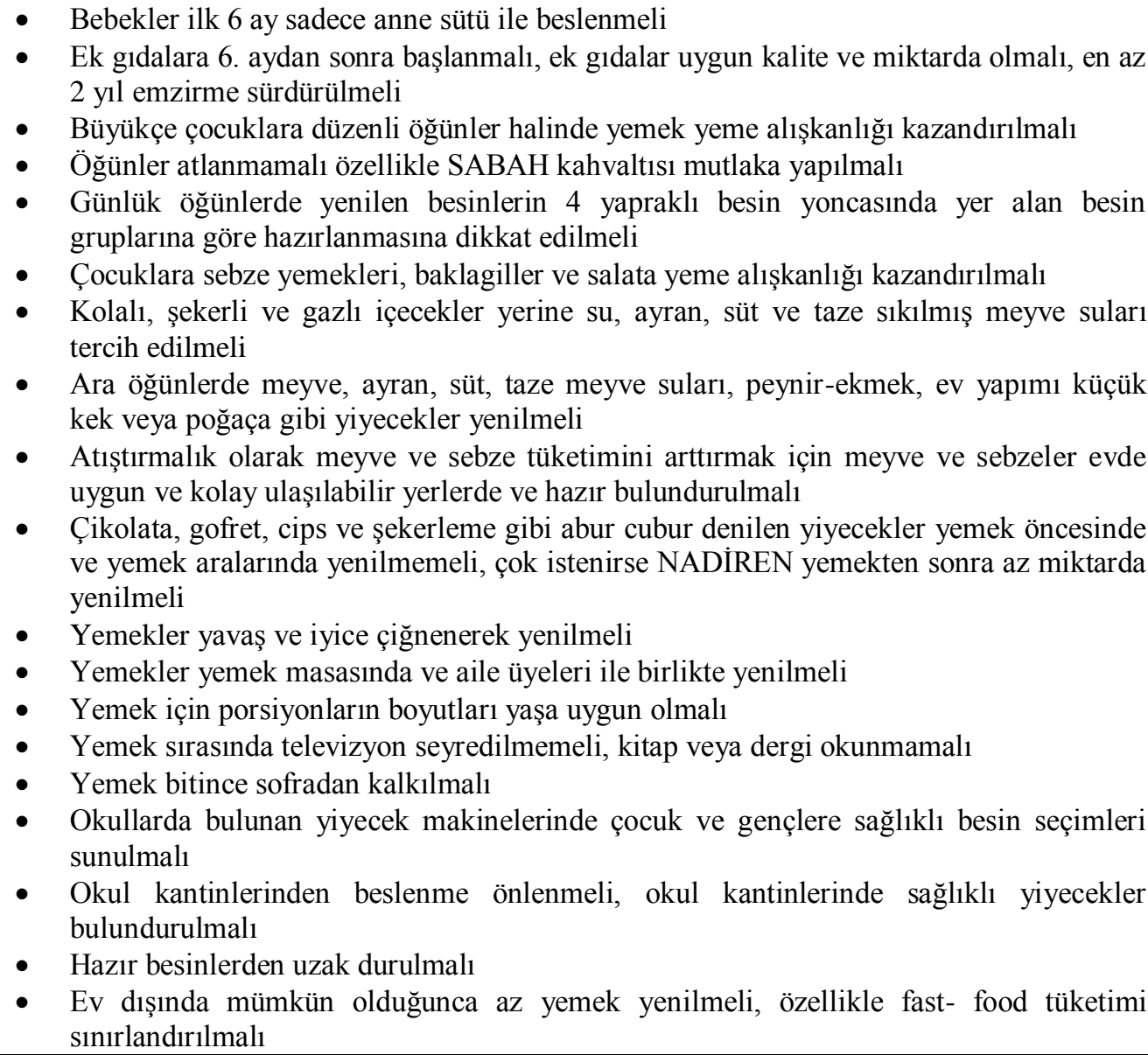 \\
\hline $\begin{array}{l}\text { Fiziksel } \\
\text { Aktiviteye } \\
\text { Yönelik } \\
\text { Öneriler }\end{array}$ & $\begin{array}{ll}\text { - } & \text { Asansör yerine merdiven kullanılmalı } \\
\text { - } & \text { Yakın mesafelere yürüyerek gidilmeli } \\
\text { - } & \text { Ev ve bahçe işlerine yardım edilmeli } \\
\text { - } & \text { Her gün } 1 \text { saat süreyle fiziksel aktivite yapılmalı } \\
\text { - } & \text { Hareketli yaşamdan hoşlanmak için öncelikle hoşa giden keyif alınacak bir aktivite } \\
\text { - } & \text { seçilmeli (voleybol, basketbol, yürüme, ip atlama gibi.) } \\
\text { - } & \text { edilmeli bocuklerinin birlikte yapabileceği yürüyüş, dans, top oyunları gibi aktiviteler tercih } \\
\text { - } & \text { Okuldan sonra ve ev ödevlerini yapmadan önce dışarıda aktif oyunlar } \\
\text { - } & \text { Güvenli olan ve mümkün olan her şartta yürüyüş yapıllmalı } \\
\end{array}$ \\
\hline $\begin{array}{l}\text { Sedanter } \\
\text { Davranışa } \\
\text { Yönelik } \\
\text { Öneriler }\end{array}$ & $\begin{array}{l}\text { - Günlük olarak televizyon ve bilgisayar başında geçirilen süre en fazla } 2 \text { saatle } \\
\text { sinırlandırılmalı } \\
\text { - Çocuğun uyuduğu odada televizyon bulundurulmamalı, çocuğun yaşı } 2 \text { yaşından küçük } \\
\text { ise hiç televizyon seyrettirilmemeli } \\
\text { - Televizyon izlerken, bilgisayar başında çalışırken veya sadece dinlenirken bir defada } \\
\text { 30dk. dan fazla oturulmamalı }\end{array}$ \\
\hline
\end{tabular}




\section{HEMŞIRELIK}

Hemşireler, ebeveynleri pasif aktiviteleri sınırlandırmaları konusunda da bilgilendirmelidir. Çocuklar televizyon izleme, bilgisayar kullanma ve pasif oyunlar yerine aktif oyunlara yönlendirilmelidir. Ebeveynler çocuklarının televizyon izleme sürelerini sınırlandırmaları, televizyon izlerken yanlarında bulunmaları ve bu sırada neler yediklerini izlemeleri konusunda uyarılmalıdır. ${ }^{5}$

\section{Üçüncül koruma}

$\mathrm{Bu}$ aşamada çocukluk çağı obezitesine yönelik yapılacak girişimler sınırlıdır ve konusunda uzman olan multidisipliner bir ekip tarafından yürütülür. Ekip üyeleri doktor, hemşire, diyetisyen, psikolog ve egzersiz danışmanından(fiziksel aktivite uzmanı) oluşur. Bu düzeydeki girişimler çok ciddi düzeyde obez olan, yaşam tarzını değiştirmeye yönelik girişimlerinde (fiziksel aktivite ve beslenme davranışı) başarılı olamamış ve kilosu değişmemiş, obeziteye bağlı sağlık sorunları/riskleri olan çocuk ve adolesanlara faydalı olabilir. Obez çocuğa veya adolesana yapılacak girişimler bir protokol çerçevesinde uygulanır. $\mathrm{Bu}$ protokol; beslenme ve aktivite danışmanlığı, öğünlerin belirlenmesi, başlangıçta düşük enerjili diyet uygulaması ve gerekirse hekim önerisiyle adolesan gruba ilaç tedavisini ya da cerrahi uygulamaları içermektedir. İlaç tedavisinin etkin olabilmesi için diyet ve aktivite uygulamasıyla birlikte yürütülmesi gerekir. Konusunda uzman olan hemşire bu aşamada multidisipliner ekip ile birlikte hareket eder. ${ }^{11}$

\section{Sonuç}

Günümüzde çocukluk çağının en sık görülen kronik hastalıklardan biri olan obezite, yetişkinlik obezitesine yol açtığı ve pek çok kronik hastalık için zemin oluşturduğundan, önleme çalışmalarına çocukluk çağında başlanması önemlidir. ${ }^{12,34}$ Hemşirelerin yenidoğan ve bebeklik döneminde emziren annelere fiziksel ve emosyonel yönden destek sağlayarak yaşamın ilk 6 ayında sadece anne sütünün verilmesi, 6.aydan sonra emzirmenin sürdürülmesi ile birlikte uygun kalite ve miktardaki tamamlayıcı besinlere başlanılması ve en az 2 yıl emzirmenin sürdürülmesinin sağlanması, ${ }^{1,38}$ çocuğun ve adolesanın yaşına uygun beslenmenin sağlanması, aile üyelerinin bir arada evde yemek yemeleri, yemek sirasında televizyon seyretme ya da kitap okuma gibi dikkati başka yöne çeken davranışların yapılmaması, yemekler arasında atıştırmanın kaldırılması ve üç ana üç ara ögün şeklinde yenilmesi, günlük fiziksel aktivitenin düzenlenmesi (en az 60 dak.), tartı kaybettikçe çocuğa ödül uygulanması, yeme ve aktivite davranışlarıyla ebeveynlerin çocuklarına model oluşturması obezite ile mücadelede başarıya ulaşmayı sağlayacaktır. ${ }^{6,35,41}$ 


\section{Kaynaklar}

1. American Nurses Association (ANA), Ana Issue Brief, Information and analysis on topics affecting nurses, the profession and health care, The Imperative of Breastfeeding, Policy changes to promote the health and economic benefits of infant feeding 2010. [updated 2011 May; cited 2014 August 8]. Available from: http://www.nursingworld.org/MainMenuCategories/Policy-Advocacy/Positions-andResolutions/Issue-Briefs/Breastfeeding.pdf

2. Arslan P. Çocukluk ve adölesan çağı şişmanlığın diyet tedavisi ilkeleri. Turkish Journal of Endocrinology and Metabolism 2003; 7(2): 27-32.

3. Aydın A. Çocukluk çağı obezitesi. Klinik Çocuk Forumu 2008; 8(1):38-45.

4. Baltacı G. Obezite ve Egzersiz. 1.Baskı. Ankara: Sağlık Bakanlığı Yayın No: 730, Klasmat Matbaac1lık; 2008.

5. Barlow SE. Expert committee recommendations regarding the prevention, assessment, and treatment of child and adolescent overweight and obesity: Summary report. PEDIATRICS 2007; 120 (Suppl 4):S164-S192.

6. Ben-Sefer E, Ben-Natan M, Ehrenfeld M. Childhood obesity: current literature, policy and implications for practice. International Nursing Review 2009; 56(2): 166-173.

7. Cali AMG, Caprio S. Prediabetes and type 2 diabetes in youth: an emerging epidemic disease? Curr Opin Endocrinol Diabetes Obes 2008;15(2):123-127.

8. Chen JL, Weiss S, Heyman MB, Vittinghoff E, Lustig R. Pilot study of an individually tailored educational program bymail to promote healthy weight in Chinese American children. J Spec Pediatr Nurs 2008;13(3): 212-222.

9. Cinaz P. Çocukluk çağında obezite. Hasanoğlu E, Düşünsel R, Bideci A, editör. Temel Pediatri. 1. Baskı. Ankara: Güneş Tıp Kitabevleri Ltd. Şti; 2010. s. 59-65.

10. Cinaz P. Obezite. Clinic Pediatri 2007; 2(6):19-23.

11. Davis MM, Gance-Cleveland B, Hassink S, Johnson R, Paradis G, Resnicow K. Recommendations for prevention of childhood obesity. PEDIATRICS 2007; 120 (Suppl 4):S229-S253.

12. Demattia L, Denney SL. Childhood obesity prevention: Successful community-based efforts. The ANNALS of the American Academy of Political and Social Science 2008; 615(1):83-99.

13. Golan M, Crow S. Parents are key players in the prevention and treatment of weightrelated problems. Nutrition Reviews 2004a; 62(1):39-50. 


\section{HEMŞIRELIK}

14. Golan M, Kaufman V, Shahar DR. Childhood obesity treatment: Targeting parents exclusively v. parents and children. British Journal of Nutrition 2006; 95(5):1008-1015.

15. Gönöz H. Şişmanlık. Neyzi O, Ertuğrul TY, editör. Pediatri. 3. Baskı. İstanbul: Nobel Kitabevleri Ltd Şti; 2002. s. 221-226.

16. Griffiths LJ, Parsons TJ, Hill AJ. Self-esteem and quality of life in obese children and adolescents: a systematic review. Int J Pediatr Obes 2010; 5(4):282-304.

17. Harder T, Bergmann R, Kallischnigg G, Plagemann A. Duration of breastfeeding and risk of overweight: A meta-analysis. Am J Epidemiol 2005;162(5):397-403.

18. Karaağaoğlu N. İlköğretim Çocukları İçin Sağlıklı Beslenme. 1. Baskı. Ankara: Sağlık Bakanlığ1 Yayın No:726, Klasmat Matbaacılık; 2008.

19. Karasalihoğlu S. Çocukluk çağı obezitesi. Türkiye Klinikleri J Int Med Sci 2005;1(37):6671.

20. Khodaverdi F, Alhani F, Kazemnejad ,A, Khodaverdi Z. (2011). The relationship between obesity and quality of life in school children. Iranian J Publ Health 2011; 40(2): 96-101.

21. Köksal G, Özel HG. Çocukluk ve Ergenlik Döneminde Obezite. 1.Baskı. Ankara: Sağlık Bakanlığı Yayın No: 729, Klasmat Matbaacılık; 2008.

22. Lazarou C, Kouta C. The role of nurses in the prevention and management of obesity. British Journal of Nursing 2010; 19(10):641-647.

23. Li S, Chen W, Srinivasan SR, Bond MG, Tang R, Urbina EM, et al. Childhood cardiovascular risk factors and carotid vascular changes in adulthood: The Bogalusa Heart Study. JAMA 2003;290(17):2271-2276.

24. Ogden CL, Carroll MD, Kit BK, Flegal KM. Prevalence of childhood and adult obesity in the United States, 2011-2012. JAMA 2014; 311(8):806-814.

25. Özbek MN, Topaloğlu AK. Çocukluk çağında obezite. Türkiye Klinikleri Pediatrik Bilimler Dergisi 2007; 3(6): 47-50.

26. Özcebe H, Tezcan S, Güner P. Çocuklarda obezite sorunu ve ö mler. Çocuk Dergisi 2005; $5(1): 15-20$.

27. Paul IM, Bartok CJ, Downs DS, Stifter CA, Ventura AK, Birch LL. Opportunities for the primary prevention of obesity during infancy. Adv Pediatr 2009;56(1): 107-133.

28. Saunders D, Harrison B. Application of the epidemiological model: Community-based interventions for the management of obesity in children and young adults . Forum on Public Policy [serial on the Internet]. 2007 [ cited 2014 Aug 8]; 2007 (1). Available from: http://forumonpublicpolicy.com/archive07/saunders.pdf 
29. Snethen JA, Broome ME, Kelber S, Leicht S, Joachim J, Goretzke M. Dietary and physical activity patterns: Examining fathers' perspectives. JSPN 2008;13(3):201-211.

30. Spear BA, Barlow SE, Ervin C, Ludwig DS, Saelens BE, Schetzina KE, et al. Recommendations for treatment of child and adolescent overweight and obesity. PEDIATRICS 2007; 120(Suppl 4): S254-S288.

31. Strong G, Lee S. Breastfeeding to combat childhood obesity the duration reguired to reduce the risk. Clinical Lactation 2012; 3 (4): 143-146.

32. T.C. Sağlık Bakanlığı Sağlık Araştırmaları Genel Müdürlüğü, Hacettepe Üniversitesi Sağlık Bilimleri Fakültesi Beslenme ve Diyetetik Bölümü, Ankara Numune Eğitim ve Araştırma Hastanesi. Türkiye Beslenme ve Sağlı Araştırması 2010: Beslenme Durumu ve Alışkanlıklarının Değerlendirilmesi Sonuç Raporu. Sağlık Bakanlığı Yayın No: 931, Ankara 2014.

33. T.C. Sağlık Bakanlığı Türkiye Halk Sağlığı Kurumu Türkiye Sağlıklı Beslenme ve Hareketli Hayat Programı (2014 - 2017). Sağlık Bakanlığı Yayın No: 773, Ankara 2013.

34. Tarım Ö. Pediatrik obeziteye genel bakış. Güncel Pediatri Dergisi 2006; 4(Özel Sayı 1):28-31.

35. The Report of the National Taskforce on Obesity, The Policy Challenges 2005. [cited 2014 Aug]. Available from:

http://www.hse.ie/eng/health/child/healthyeating/taskforceonobesity.pdf

36. The World Health Organization. Global strategy on diet, physical activity and health 2014 [updated 2014; cited 2014 Aug]. Available from: http://www.who.int/dietphysicalactivity/childhood/en/

37. The World Health Organization. Obesity and overweight fact sheet 2014 [updated 2014 Aug; cited 1014 Aug 8]. Available from: http://www.who.int/mediacentre/factsheets/fs311/en/

38. UNİCEF. Infant and young child feeding 2014 [updated 2014 January 16; 2014 Aug 8]. Available from: http://www.unicef.org/nutrition/index_breastfeeding.html

39. Verbeeten KC, Elks CE, Daneman D, Ong KK. Association between childhood obesity and subsequent Type 1 diabetes: a systematic review and meta-analysis. Diabet Med 2011; 28(1):10-18.

40. Wijnhoven TMA, van Raaij JMA, Spinelli A, Starc G, Hassapidou M, Spiroski I, et al. WHO European Childhood Obesity Surveillance Initiative: body mass index and level of overweight among 6-9-year-old children from school year 2007/2008 to school year 2009/2010. BMC Public Health [serial on the Internet]. 2014 [cited 2014 Aug 8]; 14(1): 
HEMŞİRELIKK

[about 806 p.]. Available from: http://www.biomedcentral.com/content/pdf/1471-2458-

14-806.pdf

41. Yalçın S. Görkem büyüyor. STED 2003; 12(11): 434-436. 